\title{
New Synthetic Applications of Sialic Acid Aldolase, a Useful Catalyst for KDO Synthesis. Relation between Substrate Conformation and Enzyme Stereoselectivity
}

\author{
Udo Kragl, ,a Astrid Gödde, ${ }^{a}$ Christian Wandrey, ${ }^{a}$ Nadège Lubin ${ }^{b}$ and Claudine Augé $b$ \\ a Forschungszentrum Jülich, Institut für Biotechnologie, 52425 Jülich, Germany \\ ${ }^{b}$ Institut de Chimie Moléculaire d'Orsay, URA CNRS 462-Bât. 420, 91405 Orsay Cedex, France
}

In the sialic acid aldolase-catalysed addition of pyruvate with $D$-arabinose leading to a mixture of 3deoxy-D-manno-oct-2-ulosonic acid (KDO) and 4-epi-KDO (both in pyranose and furanose form), a high concentration of the acceptor $\mathrm{D}$-arabinose have been found to increase the percentage of KDO up to $83 \%$. KDO synthesis scaled up in the enzyme membrane reactor is reported. New condensation products obtained from L-xylose, L-allose, D-altrose and D-ribose as substrates are described as well. Kinetic parameters for the cleavage of KDO and 4-epi-KDO and the addition reaction between pyruvate and xylose and arabinose are given. Some apparent relation between enzyme stereoselectivity and conformation and stereochemistry at carbon $\mathrm{C}-3$ of the substrate is discussed.

Sialic acid aldolase (EC 4.1.3.3), which catalyses the reversible aldol reaction of $\mathrm{N}$-acetylmannosamine and pyruvate to give $\mathrm{N}$ acetylneuraminic acid, has been extensively used in the synthesis of natural and unnatural sialic acids. ${ }^{1}$ The original procedure using immobilized enzyme has been scaled up by the use of the enzyme membrane reactor $(E M R){ }^{2}$ Moreover, sialic acid aldolase-catalysed condensation of pyruvate with D-arabinose 2 has also been reported; this was the first example of a lack of stereoselectivity of an aldolase: two diastereoisomers present in equimolar amounts were characterized in their pyranose form, as 3-deoxy-D-manno-oct-2-ulosonic acid (KDO) and 3-deoxy-Dgluco-oct-2-ulosonic acid (4-epi-KDO). ${ }^{3}$ Enzymic synthesis of $\mathrm{KDO}$, the universal component of lipopolysaccharides (LPS) in the outer membrane of Gram-negative bacteria, has been reported with KDO-8-phosphate synthetase (EC 4.1.2.16), from D-arabinose-5-phosphate and phosphoenolpyruvate. ${ }^{4}$ Moreover KDO aldolase (EC 4.1.2.23), using non-phosphorylated intermediates, has been identified in crude extracts of Gramnegative bacteria; ${ }^{5}$ this enzyme was very recently partially purified from Aureobacterium barkerei, a Gram-positive bacterium, and used in synthesis. ${ }^{6}$

We now report new findings in the sialic acid aldolasecatalysed condensation of pyruvate 1 with D-arabinose $\mathbf{2}$, allowing a practical preparation of KDO. ${ }^{7}$ Trying to find an interpretation for the occurrence of the inverted stereoselectivity with D-arabinose, we hypothesized that the inverted stereoselectivity could originate from the ${ }^{1} C_{4}$ major Darabinose conformer. This hypothesis was reinforced by the recent results of complete inversion of stereoselectivity obtained for this aldolase with various L sugars such as L-mannose, Lrhamnose, and L-talose, which are known to adopt exclusively the preferred ${ }^{1} C_{4}$ conformation. ${ }^{8.9}$ Moreover, another case of lack of selectivity with the sialic acid aldolase was reported with 3-deoxymannose, allowing us to suppose that the hydroxy group on carbon C-3 is also involved in positioning of the substrate at the active site. ${ }^{10}$ Therefore, in order to gain more insight into the selectivity of this aldolase we wanted to clarify the question: is there any relationship between the enzyme stereoselectivity and either the substrate conformation or the stereochemistry of the substrate on carbon C-3? Therefore, whereas the published results are mostly concerned with sugar substrates bearing an equatorial hydroxy group on carbon C-3, we decided to test as acceptor substrates $\mathrm{D}$ or $\mathrm{L}$ sugars bearing an axial hydroxy group at this position: i.e., L-allose, D-altrose and D-ribose. L-Xylose was also tested.
Table 1 Kinetic parameters for the cleavage of KDO 3 and 4-epi-KDO $4^{\circ}$

\begin{tabular}{lll}
\hline Substrate & $V_{\max }(\mathrm{U} / \mathrm{mg})$ & $K_{\mathrm{m}}\left(\mathrm{mmol} \mathrm{dm}^{-3}\right)$ \\
\hline KDO & 0.32 & 10 \\
4-epi-KDO & 9.5 & 2 \\
\hline
\end{tabular}

${ }^{a}$ See Experimental section for conditions.

\section{Results and Discussion}

A ten-fold excess of pyruvate 1 with respect to arabinose 2 was previously used, leading to the product of the inverted stereoselectivity of the aldolase, KDO (in the pyranose 3a and furanose $\mathbf{3 b}$ form) in addition to the product of normal stereoselectivity, 4-epi-KDO (in the pyranose $\mathbf{4 a}$ and furanose $4 \mathrm{~b}$ form) in the 3:4 ratio of 44:56 (Scheme 1). ${ }^{3}$ Other conditions were investigated here: it turned out that reversing the concentrations of substrates 1 and 2 , i.e. by the use of a large excess of acceptor 2 , drastically increased the percentage of KDO as shown in Fig. 1. For a given acceptor concentration, the amount of enzyme was also found to influence the rate of formation of KDO: by increasing the enzyme's concentration the maximum percentage of KDO was reached more quickly (Fig. 2). For the degradation reaction, kinetic parameters of KDO and 4-epi-KDO towards the sialic acid aldolase were determined (Table 1). For 4-epi-KDO, which has the same configuration at $\mathrm{C}-4$ as neuraminic acid, the natural product for the aldolase, a smaller $K_{\mathrm{m}}$-value (a higher affinity) and a higher $V_{\max }-$ value were found compared with those for KDO, indicating that for the binding and cleavage of the product this position has prime importance. This observation is very close to the previous one according to which 4-epi- $N$ acetylneuraminic acid (same configuration as KDO) was not cleaved by the aldolase, but could act as an inhibitor. ${ }^{11}$ From these results it may be concluded that the increase in the amount of the desired product, KDO, is due to two effects: the direct synthesis of KDO, and the cleavage of 4-epi-KDO. For discussing which effect is predominant, it would be necessary to know the whole kinetics of the system, especially the influence of already formed products on the reaction rate.

Synthesis of KDO was achieved with a 25 -fold excess of arabinose 2 in an enzyme membrane reactor allowing a 


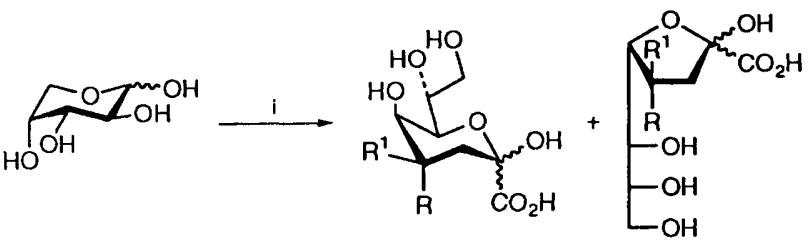

D-Arabinose 2

3a $R=H, R^{1}=\mathrm{OH} \quad 3 b \quad R=H, R^{1}=\mathrm{OH}$

4a $R=O H, R^{1}=H \quad$ 4b $R=O H, R^{1}=H$

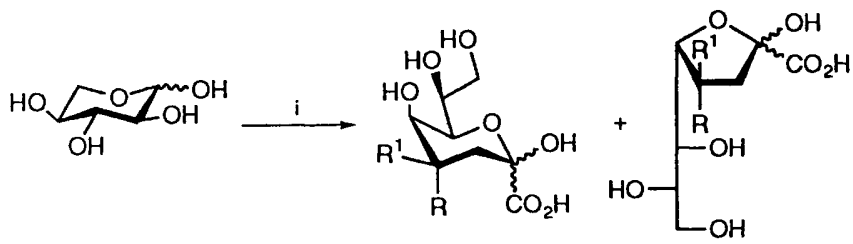

L-Xylose 5

6a $R=H, R^{1}=O H \quad 6 b \quad R=H, R^{1}=O H$

$7 a R=O H, R^{1}=H \quad 7 b R=O H, R^{1}=H$

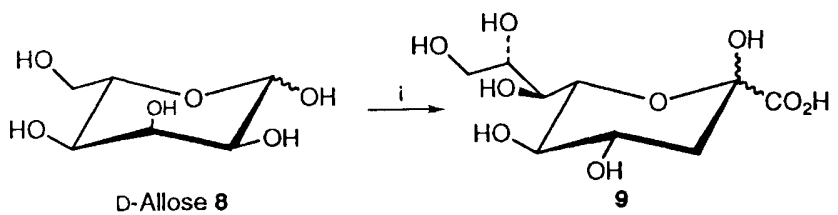

D-Allose 8

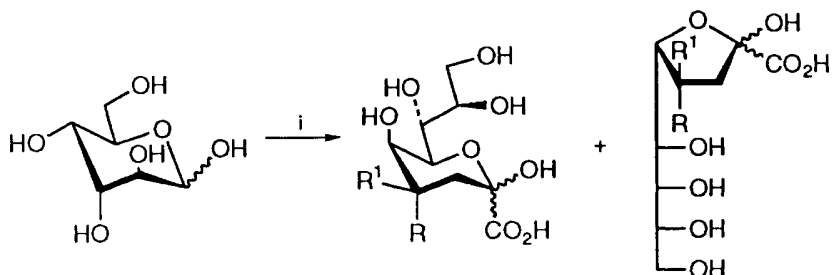

D-Altrose 10

11a $R=H, R^{1}=O H$ 11b $R=H, R^{1}=O H$ 12a $R=O H, R^{1}=H \quad 12 b \quad R=O H, R^{1}=H$

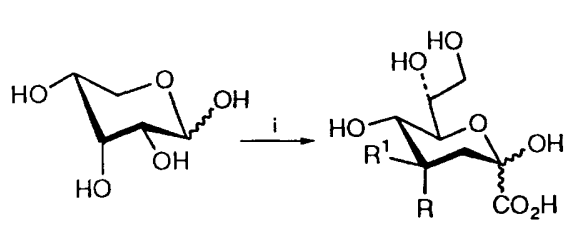

D-Ribose 13

$14 \mathrm{R}=\mathrm{H}, \mathrm{R}^{1}=\mathrm{OH}$

$$
15 a \mathrm{R}=\mathrm{OH}, \mathrm{R}^{1}=\mathrm{H}
$$

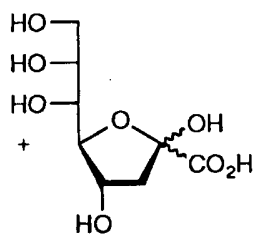

$15 b$
Scheme 1 Products of the sialic acid aldolase-catalysed addition reaction of different sugars with pyruvate, occurring in both pyranose and furanose forms. Reagents: i, sialyl aldolase and pyruvate.

continuously operating process, as previously described. ${ }^{2}$ The $3: 4$ ratio of the isolated condensation products was estimated to be $83: 17$ from HPLC, ${ }^{1} \mathrm{H}$ and ${ }^{13} \mathrm{C}$ NMR spectroscopy. In particular, the ratio of both diastereoisomers was easily evaluated from the intensity of the signals for carbon C-3 occurring at $\delta_{\mathrm{c}} 33.01$ and 31.3 for $3 \mathbf{a}$ and $4 \mathbf{a}$ respectively. Furthermore, diastereoisomers were successfully separated by anion-exchange chromatography according to the published procedure $^{12}$ and KDO was isolated as a pure compound $(45 \%$ yield based on pyruvate 1 ). ${ }^{1} \mathrm{H}$ and ${ }^{13} \mathrm{C}$ NMR spectra of compounds 3 and 4 are consistent with the literature. ${ }^{13,14}$ No lactones were observed.

Further batch experiments using soluble or immobilized sialic acid aldolase were carried out with L-xylose 5, L-allose 8 , D-altrose 10, D-ribose 13 and pyruvate 1 in excess. The lack of stereoselectivity was observed with L-xylose 5 , whereas reaction with D-xylose was previously reported to lead to a diastereoisomerically pure compound. ${ }^{3}$ However, as in the case of

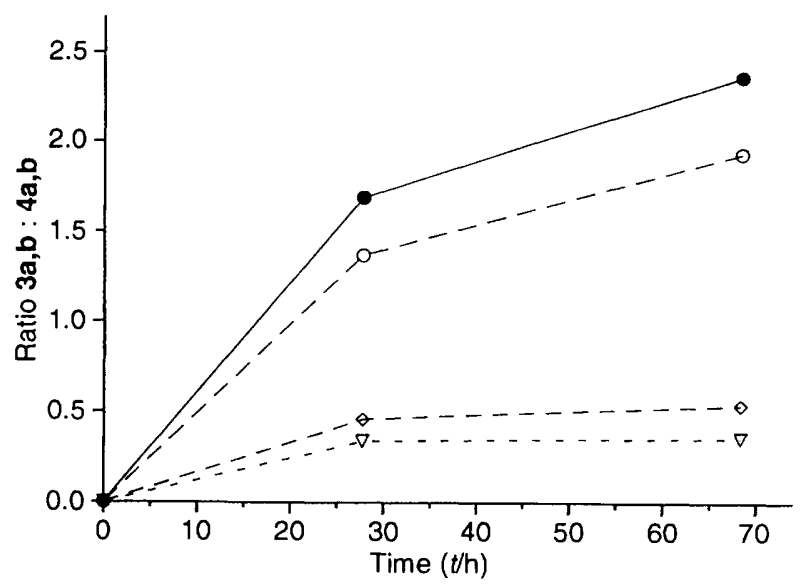

Fig. 1 KDO:4-epi-KDO ratio versus reaction time for different pyruvate 1: arabinose 2 ratios: $0,1: 21: 10\left(10 \mathrm{mmol} \mathrm{dm}^{-3} 1\right) ; \bigcirc, 1: 2$ 1:5 $\left(10 \mathrm{mmol} \mathrm{dm}^{-3} 1\right) ; \diamond, 1: 25: 1\left(10 \mathrm{mmol} \mathrm{dm}^{-3} 2\right) ; \triangle$, 1:2 $10: 1$ $\left(10 \mathrm{mmol} \mathrm{dm}{ }^{-3} 2\right) ; 0.5 \mathrm{~g} \mathrm{dm}^{-3}$ sialyl aldolase; $37^{\circ} \mathrm{C}$

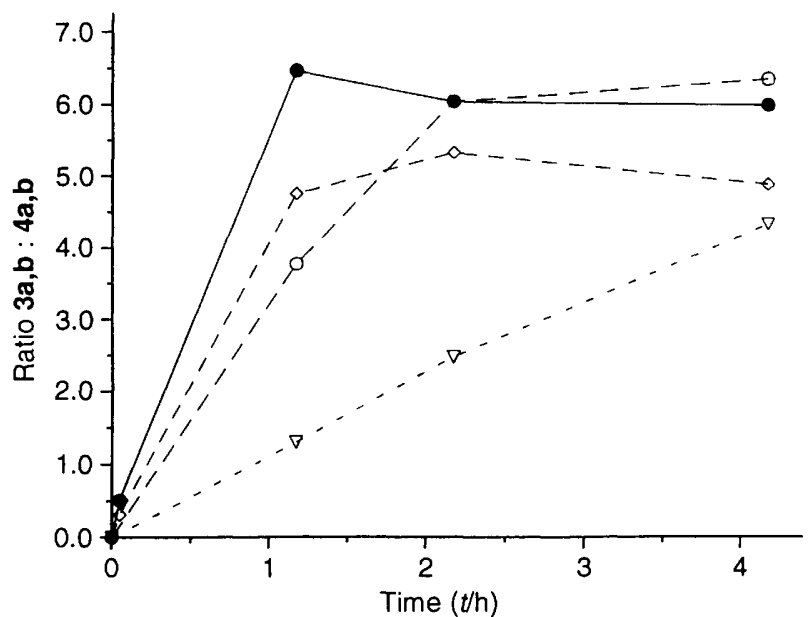

Fig. 2 KDO:4-epi-KDO ratio versus reaction time for two different pyruvate 1 : arabinose 2 ratios and two different enzyme concentrations: $0,1: 21: 25\left(20 \mathrm{mmol} \mathrm{dm}^{-3} 1\right), 8 \mathrm{~g} \mathrm{dm}^{-3}$ sialyl aldolase; $0,1: 21: 25(20$ $\left.\mathrm{mmol} \mathrm{dm}{ }^{-3} 1\right), 2 \mathrm{~g} \mathrm{dm}^{-3}$ sialyl aldolase; $\diamond, 1: 21: 10\left(50 \mathrm{mmol} \mathrm{dm}^{-3} 1\right), 8$ $\mathrm{g} \mathrm{dm}^{-3}$ sialyl aldolase; $\triangle, 1: 21: 10\left(50 \mathrm{mmol} \mathrm{dm}^{-3} \mathrm{1}\right), 2 \mathrm{~g} \mathrm{dm}^{-3}$ sialyl aldolase; $37^{\circ} \mathrm{C}$

D-arabinose, by reversing the ratio of donor 1 to acceptor 5 , the $38: 62$ ratio $(46 \%$ yield) of products $6 \mathbf{a}, 6 \mathbf{b}: 7 \mathbf{a}, 7 \mathbf{b}$ could be enhanced up to $75 \%$ in favour of $7-e p i-\mathrm{KDO}, \mathbf{6 a}, \mathbf{b}$. Under the same conditions, condensation with $L$-allose 8 led to diastereoisomerically pure 7,8-di-epi-KDN 3-deoxy-L-glycero-Laltro-non-2-ulosonic acid 9 (42\% yield), a result similar to that observed for two other L-sugars, L-arabinose and L-gulose. ${ }^{9}$ The NMR spectrum of 9 is in good accordance with the values reported for 7,8-di-epi-Neu5Ac. ${ }^{15}$ On the other hand, condensation with D-altrose $\mathbf{1 0}$ afforded a mixture of diastereoisomers 11a, 11b and $\mathbf{1 2 a}, \mathbf{1 2 b}$ in the ratio $84: 16(51 \%$ yield), with predominance of the C-9 homologue of KDO, 11 . Finally, conversion of D-ribose 13 also led to a mixture of 5-epiKDO 14 and 4,5-di-epi-KDO 15a, 15b in the ratio 45: 55, as in the case of D-arabinose 2. It is noteworthy that in that case the product of the inverted stereoselectivity is occurring exclusively in the pyranose form, as evidenced by the ${ }^{1} \mathrm{H}$ NMR signals for 3 $\mathrm{H}^{\mathrm{ax}}$ and $3-\mathrm{H}^{\mathrm{eq}}$ in good agreement with the values reported in the literature; ${ }^{6}$ on the other hand the product of normal stereoselectivity is occurring in both furanose and pyranose forms. NMR data of compound 15 were compared with those of related compounds recently obtained by chemical synthesis. ${ }^{16}$ Whereas KDO-related compounds $4,11,12,14$ might be 
Table 2 Sialic acid aldolase-catalysed addition reaction of 1 with various sugars

\begin{tabular}{|c|c|c|c|c|c|}
\hline Acceptor & $\begin{array}{l}\text { Reaction } \\
\text { conditions }^{a}\end{array}$ & $\begin{array}{l}\text { Products of } \\
\text { normal } \\
\text { selectivity }\end{array}$ & $\begin{array}{l}\text { Products of } \\
\text { inverted } \\
\text { selectivity }\end{array}$ & $\begin{array}{l}\text { Ratio }^{b} \text { of } \\
\text { inverted: normal } \\
\text { selectivity }\end{array}$ & $\begin{array}{l}\text { Total } \\
\text { isolated } \\
\text { yield }(\%)\end{array}$ \\
\hline 2 & $\mathbf{a}$ & $4 a, b$ & $\mathbf{3 a}, \mathbf{b}$ & $44: 56$ & $35^{c}$ \\
\hline 2 & c & $4 a, b$ & 3a, b & $83: 17$ & 75 \\
\hline 5 & a & $7 \mathbf{a}, \mathbf{b}$ & 6a, b & $38: 62$ & 46 \\
\hline 5 & b & $7 \mathbf{a}, \mathbf{b}$ & 6a, b & $75: 25$ & 60 \\
\hline 8 & $\mathrm{a}$ & 9 & & $0: 100$ & 42 \\
\hline 10 & $\mathrm{a}$ & $12 \mathrm{a}, \mathrm{b}$ & $11 \mathbf{a}, \mathbf{b}$ & $84: 16$ & 51 \\
\hline 13 & $\mathrm{a}$ & $15 \mathbf{a}, \mathbf{b}$ & 14 & $45: 55$ & 23 \\
\hline
\end{tabular}

${ }^{a}$ See Experimental section for conditions (a) and (b). Conditions (c) correspond to the continuous process using the enzyme membrane reactor. ${ }^{b}$ Determined by NMR spectroscopy. ${ }^{c}$ See ref. 3 .

Table 3 Stereoselectivity of the sialic acid aldolase-catalysed reaction depending on substrate conformation and substrate stereochemistry on carbon C-3

\begin{tabular}{|c|c|c|c|}
\hline Conformation & $\begin{array}{l}\text { Normal selectivity } \\
s i \text {-face attack } \\
\text { leading to KDN-type } \\
\text { product }\end{array}$ & $\begin{array}{l}\text { Inverted selectivity } \\
\text { re-face attack } \\
\text { leading to KDO-type product }\end{array}$ & $\begin{array}{l}\text { Lack of selectivity } \\
\text { re- and } s i \text {-face attack } \\
\text { leading to KDO-type and } \\
\text { 4-epi-KDO-type products }\end{array}$ \\
\hline${ }^{4} C_{1}$ & $\begin{array}{l}N \text {-Acetyl-D-mannosamine }{ }^{a} \\
\text { D-Mannose }^{a} \\
\text { 2-Azido-D-mannose } \\
\text { D-Glucose }^{a} \\
\text { 2-Deoxy-D-glucose } \\
\text { D-Lyxose }^{a} \\
\text { D-Talose }^{b} \\
\text { D-Xylose }^{a} \\
\text { L-Arabinose }^{b}\end{array}$ & No example & $\begin{array}{l}\text { D-Altrose } \\
\text { D-Gulose } \\
\text { D-Ribose } \\
\text { 3-Deoxy-D-mannose }{ }^{a}\end{array}$ \\
\hline${ }^{1} C_{4}$ & $\begin{array}{l}\text { L-Allose } \\
\text { L-Gulose }^{b}\end{array}$ & $\begin{array}{l}N \text {-Acetyl-L-mannosamine } \\
\text { L-Mannose }^{b} \\
\text { 2-Deoxy-L-glucose } \\
\text { L-Rhamnose }^{b} \\
\text { 2-Deoxy-L-rhamnose } \\
\text { L-Talose }^{b}\end{array}$ & $\begin{array}{l}\text { D-Arabinose }{ }^{a} \\
\text { L-Xylose } \\
\text { 2-Azido-L-mannose }\end{array}$ \\
\hline
\end{tabular}

${ }^{a}$ Refs. 3 and $10 .{ }^{b}$ Refs. 8 and 9.

potential inhibitors of the cytidine monophosphate KDO synthetase ${ }^{17}$ neuraminic acid-related compounds 9 and 15b could be sialidase inhibitors; the Neu5Ac analogue of compound $\mathbf{1 5 b}$ has just been reported as a powerful sialidase inhibitor. ${ }^{16}$ All results are summarized in Table 2.

In view of the large range of experimental results reported by Wong's group and by us (summarized in Table 3 ), it clearly appears that the orientation of the hydroxy group on carbon $\mathrm{C}$ 3 is critical for the enzyme's selectivity. Therefore we think that the ring form of the sugar is first bound to the enzyme. The next step may be ring opening to get some kind of open-chain form of the sugar. However, it is not possible to give a satisfying explanation of how the neighbouring $\mathrm{C}$ atoms affect the direction of the attack. In spite of this fact, some general features can be drawn. Concerning pentoses and hexoses occurring in the ${ }^{4} C_{1}$ conformation, the equatorial orientation of the hydroxy group on carbon C-3 ensures the normal stereoselectivity, resulting from $s i$-face attack of the aldehyde by the nucleophile. The binding of these sugars (D-glucose, $D$ mannose, D-talose, D-lyxose, D-xylose, L-arabinose) to the active site is analogous to the binding of the natural substrate,
$\mathrm{N}$-acetyl-D-mannosamine. Scheme 2 shows a suggested mechanism for the sialic acid aldolase, based on the findings of Brossmer. ${ }^{18}$ A lack of stereoselectivity was observed with Dsugars such as D-gulose, D-altrose and D-ribose (in the ${ }^{4} C_{1}$ conformation) which do not possess the hydroxy group on carbon C-3 in an equatorial orientation; for the attachment of the substrate at the active site, another mechanism might be involved. Similarly, concerning the L-hexose substrates occurring in the ${ }^{1} C_{4}$ conformation, the equatorial orientation of the hydroxy group on carbon C-3 ensures the inverted stereoselectivity, resulting from $r e$-face attack of the aldehyde. These substrates (L-mannose, L-rhamnose, L-talose) ${ }^{9,11}$ may mimic in their binding at the active site the natural enzyme product, $\mathrm{N}$-acetylneuraminic acid, occurring in the ${ }^{2} C_{5}$ conformation. However, it is noteworthy that this condition does not hold for the pentoses, D-arabinose and L-xylose, for which a lack of stereoselectivity was observed, and also for Lglucose which failed to be a substrate of the sialic acid aldolase. Special attention has to be paid to $L$-gulose ${ }^{9}$ and L-allose which do not satisfy the prerequisite condition and which behave, like L-arabinose, as ${ }^{4} C_{1}$ conformers with their hydroxy group on 


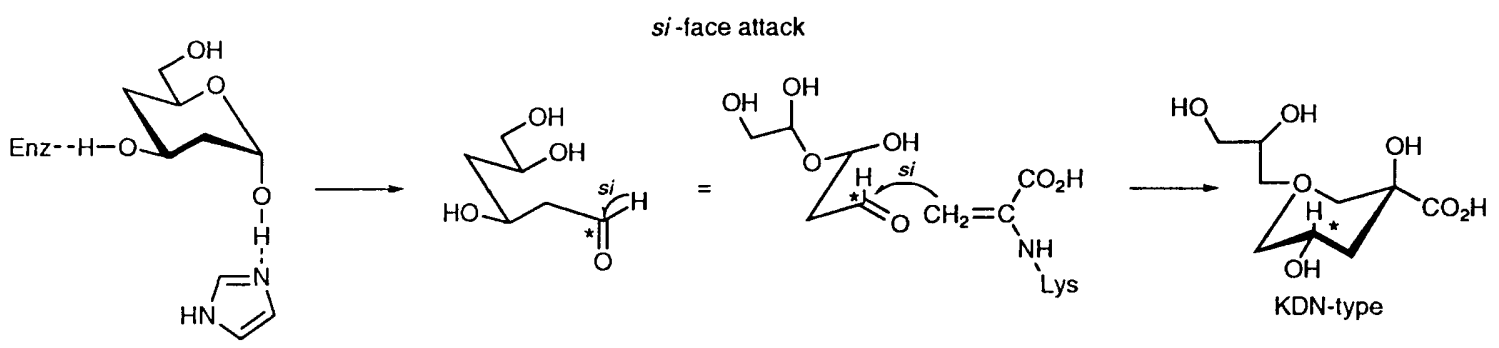

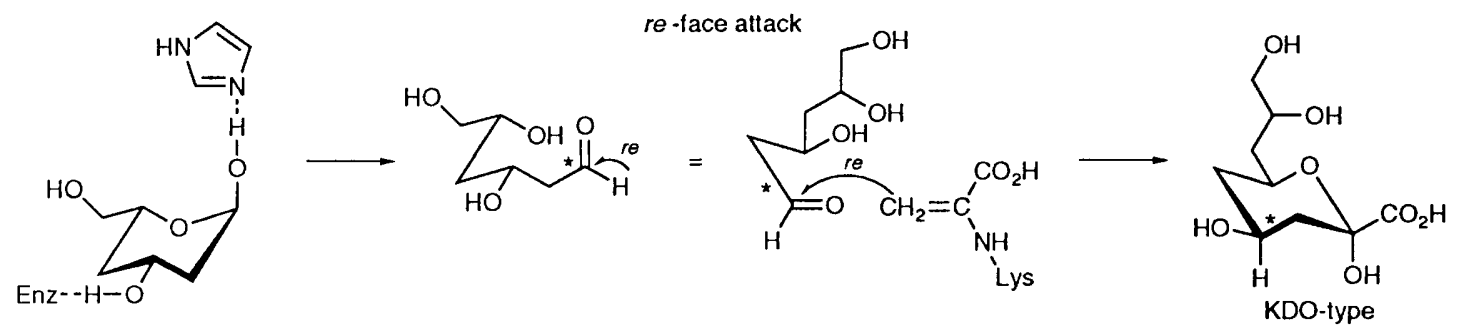

Scheme 2 Suggested mechanism for sialic acid aldolase in si face and re face attack

Table 4 Kinetic parameters for the conversion of arabinose and xylose

\begin{tabular}{lll}
\hline Sugars & $V_{\max }(\mathrm{U} / \mathrm{mg})$ & $K_{\mathrm{m}}\left(\mathrm{mol} \mathrm{dm}^{-3}\right)$ \\
\hline L-Xylose & 0.44 & 0.32 \\
D-Xylose & 0.84 & 0.21 \\
L-Arabinose & 1.4 & 0.5 \\
D-Arabinose & 1.42 & 0.84 \\
\hline
\end{tabular}

carbon $\mathrm{C}-3$ in the equatorial orientation. These sugars exist predominantly as ${ }^{1} C_{4}$ conformers $\left(\Delta G^{0}\right.$ between ${ }^{4} C_{1}$ and ${ }^{1} C_{4}$ is, respectively, 0.75 and $1.45 \mathrm{kcal} \mathrm{mol}^{-1}$ for $\alpha$-D-gulose and $\alpha$-Dallose). ${ }^{* 19} \mathrm{~A}$ change of conformation induced by additional interactions when the substrate is bound to the active site may compensate for this difference in free energy. A comparison of kinetic parameters (Table 4 and ref. 9) obtained for the conversion of various carbohydrates shows that substrates leading to products of normal stereoselectivity react faster than do substrates leading to inverted stereoselectivity or causing a lack of stereoselectivity.

Sialic acid has been cloned, and characterized to a large extent. Even crystallization has been reported, letting us hope to have better knowledge of the structure of the active site in the near future in order to elucidate fully its enzymic mechanism and to explain the observed changes in stereoselectivity. ${ }^{20}$

\section{Experimental}

General.-Sialic acid aldolase was obtained from Toyobo, Osaka, Japan. All enzyme concentrations given in $\mathrm{U} \mathrm{cm}^{-3}$ are based on the specific activity, determined for the cleavage of $N$ acetylneuraminic acid (Neu5Ac) at $37^{\circ} \mathrm{C}$ at $\mathrm{pH} \mathrm{7.5,} \mathrm{which} \mathrm{is}$ $25 \mathrm{U} \mathrm{mg}^{-1}$.

Relative and absolute amounts of carbohydrates and pyruvate were determined by HPLC: two columns $(300 \times 7.8$ $\mathrm{mm}$ ) BioRad Aminex HPX-87H in series, $6 \mathrm{mmol} \mathrm{dm}^{-3}$ sulfuric acid eluent, flow rate $0.8 \mathrm{~cm}^{3} \mathrm{~min}^{-1}$ at $65^{\circ} \mathrm{C}$; RI-detector and UV-detector (205 nm).

NMR spectra were measured in $\mathrm{D}_{2} \mathrm{O}$ at $\mathrm{pH} 7$ on a Bruker AM-250 spectrometer. ${ }^{1} \mathrm{H}$ NMR data $\left(\delta 250 \mathrm{MHz} ; \mathrm{HOD}\right.$ at $\delta_{\mathrm{H}}$ $4.80)$ and ${ }^{13} \mathrm{C}$ NMR data $\left(\delta 62.5 \mathrm{MHz}\right.$; dioxane at $\left.\delta_{\mathrm{C}} 66.64\right)$ are given relative to $\mathrm{SiMe}_{4} . J$ Values are given in $\mathrm{Hz}$.

$* 1 \mathrm{cal}=4.184 \mathrm{~J}$.
Optical rotations were measured with a Jasco digital micropolarimeter and are given in units of $10^{-1} \mathrm{deg} \mathrm{cm}^{2} \mathrm{~g}^{-1}$.

Practical synthesis of KDO was performed in the enzyme membrane reactor (EMR) as previously described. ${ }^{2}$ The enzyme, in homogeneous solution, is retained in the reactor by an ultrafiltration membrane that is permeable only to the substrates and products. The lab-scale version of the EMR used here is commercially available (volume $10 \mathrm{~cm}^{3}$, membrane diameter $62 \mathrm{~mm}$; Bioengineering, Wald, Switzerland). An Amicon YM 5 membrane was used. Main advantages of this technique are: no mass-transfer limitations, no loss of enzyme activity during immobilization steps, and high volumetric activity of enzymes. Substrates are pumped through a sterile filter at a constant flow corresponding to a constant residence time. The set-up was sterilized before use by heating to $121{ }^{\circ} \mathrm{C}$ for $20 \mathrm{~min}$ in an autoclave. By use of phosphate buffer $(50 \mathrm{mmol}$ $\left.\mathrm{dm}^{-3} ; \mathrm{pH} 7.5\right)$, bovine serum albumin $(10 \mathrm{mg})$ was pumped in the reactor for pretreatment of the membrane, followed by sialic acid aldolase $(72 \mathrm{mg})$, resulting in $7.2 \mathrm{mg} \mathrm{cm}^{-3}=180 \mathrm{U} \mathrm{cm}^{-3}$. Substrate solution $\left(20 \mathrm{mmol} \mathrm{dm}^{-3} 1,500 \mathrm{mmol} \mathrm{dm}^{-3} 2, \mathrm{pH} 7.5\right)$ was pumped through the reactor with a flow of $5 \mathrm{~cm}^{3} \mathrm{~h}^{-1}$, resulting in a residence time of $120 \mathrm{~min}$. Temperature was kept at $25^{\circ} \mathrm{C}$. For a total running time of $160 \mathrm{~h}$ pyruvate conversion was $75 \%$ (based on HPLC). An aliquot was purified by anionexchange chromatography on Dowex 1X8, 200-400 mesh, formate form, without separation of diastereoisomers, ratio KDO:4-epi-KDO $=5: 1$; furthermore, diastereoisomers could be separated on the same resin, hydrogen carbonate form, by using gradient elution with aq. ammonium hydrogen carbonate $\left(0-0.2 \mathrm{~mol} \mathrm{dm}^{-3}\right)$. In total $1.8 \mathrm{~g}$ of pure $3(45 \%), 0.22 \mathrm{~g}$ of pure 4 $(5.5 \%)$, and $0.28 \mathrm{~g}$ of a mixture of 3 and $4(7 \%)$ were obtained.

Batch experiments with soluble or immobilized sialic acid aldolase were carrid out according to procedure (a) or (b): (a) $100 \mathrm{mmol} \mathrm{dm}^{-3}$ sugar acceptor, $1 \mathrm{~mol} \mathrm{dm}^{-3} 1,50 \mathrm{mmol} \mathrm{dm}$ sodium phosphate buffer $\left(\mathrm{pH} 7.0 ; 10 \mathrm{~cm}^{3}\right), 0.01 \% \mathrm{NaN}_{3}$, $10 \mathrm{U}_{\text {enzyme. }}{ }^{1}$ (b) $1 \mathrm{~mol} \mathrm{dm}^{-3}$ sugar acceptor, $100 \mathrm{mmol} \mathrm{dm}^{-3}$ $1,50 \mathrm{mmol} \mathrm{dm}{ }^{-3}$ sodium phosphate buffer $\left(\mathrm{pH} 7.0 ; 10 \mathrm{~cm}^{3}\right.$ ), $0.01 \% \mathrm{NaN}_{3}, 10 \mathrm{U}$ enzyme. Reaction mixtures were incubated for 4 days at $37^{\circ} \mathrm{C}$.

Reactions for determination of kinetic parameters were carried out in phosphate buffer, pH 7.5 at $30^{\circ} \mathrm{C}$. For the cleavage of KDO and epi-KDO enzyme concentrations of $10 \mu \mathrm{g}$ $\mathrm{cm}^{-3}$ (KDO) or $2.5 \mu \mathrm{g} \mathrm{cm}^{-3}$ (4-epi-KDO) were used; the amount of carbohydrate was varied between 1.25 and $20 \mathrm{mmol} \mathrm{dm}^{-3}$. Periodically aliquots $\left(20 \mathrm{~mm}^{3}\right)$ of solutions were withdrawn and mixed with an assay solution $\left(0.88 \mathrm{~cm}^{3}\right)$ containing $0.1 \mathrm{~mol}$ 
$\mathrm{dm}^{-3}$ phosphate buffer (pH 7.5), $0.2 \mathrm{mmol} \mathrm{dm}^{-3}$ 1,4-dihydronicotinamide adenine dinucleotide (NADH) and $13.75 \mathrm{U}$ of $\mathrm{L}-$ lactate dehydrogenase. The amount of pyruvate formed was calculated from the disappearance of NADH, measured at 340 $\mathrm{nm}$, using $6220 \mathrm{dm}^{3} \mathrm{~mol}^{-1} \mathrm{~cm}^{-1}$ as the molecular absorbance coefficient. For the conversion of arabinose and xylose, enzyme concentrations of $100 \mu \mathrm{g} \mathrm{cm}^{-3}$ (D-, L-Ara, D-Xyl) or $10 \mu \mathrm{g} \mathrm{cm}^{-3}$ ( $\mathrm{L}-\mathrm{Xyl}$ ) were used. The amount of carbohydrate was varied between $0.2 \mathrm{~mol} \mathrm{dm}^{-3}$ and $3 \mathrm{~mol} \mathrm{dm}^{-3}$, whereas pyruvate was

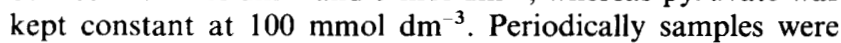
withdrawn and the amount of product formed was estimated by HPLC.

3-Deoxy-D-manno-oct-2-ulosonic Acid [3a (Pyranose), 3b (Furanose) ]- -3a: $\delta_{\mathrm{H}}(\alpha$, anomer $64 \%) 1.92\left(\mathrm{t}, 3-\mathrm{H}^{\mathrm{ax}}\right)$ and 1.83 $\left(\mathrm{dd}, 3-\mathrm{H}^{\mathrm{eq}}, J_{3 \mathrm{eq}, 3 \mathrm{ax}}=J_{3 \mathrm{ax}, 4}=12.5, J_{3 \mathrm{ax}, 4} 5.5\right) ; \delta_{\mathrm{C}} 176.9(\mathrm{C}-1)$, 96.50 (C-2), 71.24 (C-6), 69.52 (C-7), 66.72 (C-4), 66.22 (C-5), $62.91(\mathrm{C}-8)$ and $33.71(\mathrm{C}-3)$.

3b: $\delta_{\mathrm{H}}(\alpha$ anomer $19 \%, \beta$ anomer $10 \%) 2.53\left(\mathrm{dd}, 3-\mathrm{H}^{\mathrm{a}} \alpha\right), 2.31$ $\left(\mathrm{d}, 3-\mathrm{H}^{\mathrm{a}} \beta, 3-\mathrm{H}^{\mathrm{b}} \beta\right)$ and $2.02\left(\mathrm{dd}, 3-\mathrm{H}^{\mathrm{b}} \alpha\right) ; \delta_{\mathrm{C}} 103.1(\mathrm{C}-2), 85.20$ and $85.67(\mathrm{C}-5), 72.38$ and $71.89(\mathrm{C}-4), 71.65(\mathrm{C}-7), 70.63(\mathrm{C}-6)$, $60.50(\mathrm{C}-8)$ and $44.65(\mathrm{C}-3)$.

3-Deoxy-D-gluco-oct-2-ulosonic Acid [4a (Pyranose), 4b (Furanose) ]. -4a: $\delta_{\mathrm{H}}(\alpha$ anomer $56 \%) 2.19\left(\mathrm{dd}, 3-\mathrm{H}^{\mathrm{ax}}\right)$ and 1.82 $\left(\mathrm{dd}, 3-\mathrm{H}^{\text {eq }}, J_{3 \text { eq, 3ax }} 15, J_{3 \text { eq, } 4} 2, J_{3 \text { ax }, 4} 3.5\right) ; \delta_{\mathrm{C}} 176.7(\mathrm{C}-1)$, 96.05 (C-2), 69.25 (C-7), 67.54 (C-6), 67.05 (C-4), 66.02 (C-5), $62.95(\mathrm{C}-8)$ and $31.73(\mathrm{C}-3)$.

4b: $\delta_{\mathrm{H}}(\alpha$ anomer $8 \%, \beta$-anomer $28 \%) 2.51\left(\mathrm{dd}, 3-\mathrm{H}^{\mathrm{a}} \alpha\right), 2.34$ $\left(\mathrm{d}, 3-\mathrm{H}^{\mathrm{a}} \beta, 3-\mathrm{H}^{\mathrm{b}} \beta\right)$ and $2.05\left(\mathrm{dd}, 3-\mathrm{H}^{\mathrm{b}} \alpha\right) ; \delta_{\mathrm{C}} 104.3(\mathrm{C}-2), 81.30$ (C-5), $72.00(\mathrm{C}-4), 71.65(\mathrm{C}-7), 70.59(\mathrm{C}-6), 62.39(\mathrm{C}-8)$ and 43.92 (C-3).

3-Deoxy-L-gulo-oct-2-ulosonic Acid [6a (Pyranose), 6b (Furanose)]. 6a: $\delta_{\mathrm{H}}(\alpha$ anomer $62 \%) 2.03\left(\mathrm{t}, 3-\mathrm{H}^{\mathrm{ax}}\right)$ and 2.01 $\left(\mathrm{dd}, 3-\mathrm{H}^{\mathrm{eq}}, J_{3 \mathrm{eq}, 3 \mathrm{ax}}=J_{3 \mathrm{ax} .4}=13, J_{3 \mathrm{eq} .4} 5\right) ; \delta_{\mathrm{C}} 95.15(\mathrm{C}-2)$, 72.77 (C-7), 71.34 (C-6), 67.36 (C-5), 65.47 (C-4), 61.60 (C-8) and $33.01(\mathrm{C}-3)$.

6b: $\delta_{\mathrm{H}}(\alpha$ anomer $19 \%, \beta$ anomer $11 \%) 2.67\left(\mathrm{dd}, 3-\mathrm{H}^{\mathrm{a}} \alpha\right), 2.44$ $\left(\mathrm{d}, 3-\mathrm{H}^{\mathrm{a}} \beta, 3-\mathrm{H}^{\mathrm{b}} \beta\right)$ and $2.11\left(\mathrm{dd}, 3-\mathrm{H}^{\mathrm{b}} \alpha\right) ; \delta_{\mathrm{C}} 86.85(\mathrm{C}-5), 72.14$ and $71.89(\mathrm{C}-4), 68.59(\mathrm{C}-6), 67.11$ and $66.86(\mathrm{C}-7), 62.82$ and $62.47(\mathrm{C}-8), 44.07$ and $43.79(\mathrm{C}-3)$.

3-Deoxy-L-ido-oct-2-ulosonic Acid [7a (Pyranose), 7b (Furanose $)] .-7 \mathbf{a}: \delta_{\mathrm{H}}(\alpha$ anomer $47 \%) 2.26\left(\mathrm{dd}, 3-\mathrm{H}^{\mathrm{ax}}\right)$ and $1.94(\mathrm{dd}$, $\left.3-\mathrm{H}^{\mathrm{eq}}, J_{3 \mathrm{ax}, 3 \mathrm{eq}} 15, J_{3 \mathrm{eq}, 4} 2.5, J_{3 \mathrm{ax}, 4} 4\right) ; \delta_{\mathrm{C}} 71.35(\mathrm{C}-7), 68.53$ (C-6), 67.14 (C-5), 66.87 (C-4), 61.38 (C-8) and 31.30 (C-3).

$7 \mathrm{~b}: \delta_{\mathrm{H}}(\alpha$ anomer $12 \%, \beta$ anomer $21 \%) 2.66\left(\mathrm{dd}, 3-\mathrm{H}^{\mathrm{a}} \alpha\right), 2.52$ $\left(\mathrm{dd}, 3-\mathrm{H}^{\mathrm{b}} \beta\right), 2.41\left(\mathrm{dd}, 3-\mathrm{H}^{\mathrm{a}} \beta\right)$ and $2.23\left(\mathrm{dd}, 3-\mathrm{H}^{\mathrm{b}} \alpha\right) ; \delta_{\mathrm{C}} 85.47$ and $83.70(\mathrm{C}-5), 71.52$ and $71.11(\mathrm{C}-4), 70.31$ and 69.61 (C-6), 66.62 (C-7), 62.81 (C-8), 46.16 and 45.74 (C-3).

[Found: C, 37.6; $\mathrm{H}, 6.5 ; \mathrm{N}, 5.5$. Calc. for $\mathrm{C}_{8} \mathrm{H}_{17} \mathrm{NO}_{8}$ (ammonium salt of 6 and 7): $\mathrm{C}, 37.64 ; \mathrm{H}, 6.71 ; \mathrm{N}, 5.49 \%$ ].

3-Deoxy-L-glycero-L-altro-non-2-ulosonic Acid 9.- $[\alpha]_{\mathrm{D}}^{20}$ $+23.3\left(c 0.575\right.$, water); $\delta_{\mathrm{H}} 2.12\left(\mathrm{dd}, 3-\mathrm{H}^{\mathrm{eq}}, J_{3 \mathrm{eq}, 4} 5, J_{3 \mathrm{eq}, \mathrm{ax}} 12.5\right)$ and $1.75\left(\mathrm{t}, 3-\mathrm{H}^{\mathrm{ax}}, J_{3 \mathrm{ax} .4} 12\right) ; \delta_{\mathrm{C}} 39.28(\mathrm{C}-3), 63.42(\mathrm{C}-9), 69.65$ (C-4), 71.74 (C-7), 71.89 (C-5), 72.29 (C-6), 73.83 (C-8), 96.65 (C-2) and $176.9(\mathrm{C}-1)$ (Found: $\mathrm{C}, 39.5 ; \mathrm{H}, 5.85$. Calc. for $\mathrm{C}_{9} \mathrm{H}_{16} \mathrm{O}_{9} \cdot 0.5 \mathrm{H}_{2} \mathrm{O}: \mathrm{C}, 38.99 ; \mathrm{H}, 6.18 \%$ ).

3-Deoxy-D-glycero-D-manno-non-2-ulosonic Acid [11a (Pyranose), $11 \mathrm{~b}$ (Furanose)].-11a: $\delta_{\mathrm{H}} 1.95\left(\mathrm{t}, 3-\mathrm{H}^{\mathrm{ax}}, J_{4,3 \mathrm{ax}} 12.5\right.$, $\left.J_{3 \text { eq.3ax }} 12.5\right)$ and $1.83\left(\mathrm{dd}, 3-\mathrm{H}^{\mathrm{eq}}, J_{3 \mathrm{eq} .4} 5.5\right) ; \delta_{\mathrm{C}} 34.08(\mathrm{C}-3)$, 62.19 (C-9), 66.53 (C-4), 67.17 (C-5), 70.12 (C-7), 71.77 (C-6), $73.29(\mathrm{C}-8)$ and $96.82(\mathrm{C}-2)$

$11 \mathrm{~b}: \delta_{\mathrm{H}}\left(\alpha\right.$ anomer) $2.53\left(\mathrm{dd}, 3-\mathrm{H}^{\mathrm{a}}, J_{4,3 \mathrm{a}} 6.5, J_{3 \mathrm{~b}, 3 \mathrm{a}} 14\right)$ and $2.20\left(\mathrm{dd}, 3-\mathrm{H}^{\mathrm{b}}, J_{3 \mathrm{~b}, 4} 3.5\right) ; \delta_{\mathrm{C}} 45.09(\mathrm{C}-3), 62.74(\mathrm{C}-9), 85.50$ and $86.14(\mathrm{C}-2) ; \delta_{\mathrm{H}}(\beta$ anomer $) 2.27-2.37\left(3-\mathrm{H}^{\mathrm{a}}, 3-\mathrm{H}^{\mathrm{b}}\right)$.

3-Deoxy-D-glycero-D-gluco-non-2-ulosonic Acid [12a (Pyranose), 12b (Furanose)].-1a: $\delta_{\mathrm{H}} 2.03\left(\mathrm{dd}, 3-\mathrm{H}^{\mathrm{ax}}, J_{4,3 \mathrm{ax}} 1, J_{3 \mathrm{eq}, 3 \mathrm{ax}}\right.$ 12) and $1.78\left(\mathrm{~m}, 3-\mathrm{H}^{\mathrm{eq}}\right) ; \delta_{\mathrm{C}} 32.08(\mathrm{C}-3), 67.67(\mathrm{C}-7), 67.83(\mathrm{C}-4)$ and $96.44(\mathrm{C}-2)$.

12b: $\delta_{\mathrm{C}} 44.10(\mathrm{C}-3)$ and $82.0(\mathrm{C}-3)$ [Found: $\mathrm{C}, 38.2 ; \mathrm{H}, 6.2$. Calc. for $\mathrm{C}_{9} \mathrm{H}_{16} \mathrm{O}_{9} \cdot \mathrm{H}_{2} \mathrm{O}$ (11 and 12): C, 37.76; H, 6.34\%].

3-Deoxy-D-altro-oct-2-ulosonic Acid 14.- $\delta_{\mathrm{H}} 2.14\left(\mathrm{dd}, 3-\mathrm{H}^{\mathrm{eq}}\right.$, $\left.J_{4.3 \mathrm{eq}} 5, J_{3 \mathrm{eq}, 3 \mathrm{ax}} 13\right)$ and $1.75\left(\mathrm{t}, 3-\mathrm{H}^{\mathrm{ax}}, J_{4.3 \mathrm{ax}} 12.5\right) ; \delta_{\mathrm{C}} 39.29$ (C-3), 62.41 (C-8), 69.64 (C-4), 71.75 (C-5), 72.75 (C-6), 74.33 (C-7), $96.61(\mathrm{C}-2)$ and 176.87 (C-1).

3-Deoxy-D-allo-oct-2-ulosonic Acid [15a (Pyranose), 15b (Furanose)].-15a: $\delta_{\mathrm{H}} 2.05\left(\mathrm{~m}, 3-\mathrm{H}^{\mathrm{eq}}, 3-\mathrm{H}^{\mathrm{ax}}\right) ; \delta_{\mathrm{C}} 36.68(\mathrm{C}-3)$.

15b: $\left(\alpha\right.$ anomer) $\delta_{\mathrm{H}} 2.49\left(\mathrm{dd}, 3-\mathrm{H}^{\mathrm{a}}, J_{4,3 \mathrm{a}} 7, J_{3 \mathrm{a}, 3 \mathrm{~b}} 14\right)$ and $2.05\left(\mathrm{dd}, 3-\mathrm{H}^{\mathrm{b}}, J_{4.3 \mathrm{~b}} 8\right) ;(\beta$ anomer $) \delta_{\mathrm{H}} 2.32\left(\mathrm{t}, 3-\mathrm{H}^{\mathrm{b}}, 3-\mathrm{H}^{\mathrm{a}}\right)$ and $4.53(\mathrm{~m}, 4-\mathrm{H}) ; \delta_{\mathrm{C}} 45.05(\mathrm{C}-3), 87.93$ and $87.04(\mathrm{C}-2 \alpha, \beta)$.

15a, 15b (signals not assigned to pyranose or furanose form): $\delta_{\mathrm{C}} 62.77$ and $63.15(\mathrm{C}-8), 67.12$ and $68.11(\mathrm{C}-7), 70.06,71.14$, $71.61,72.14,72.32$ and 73.14 (C-4 and -6) [Found: $\mathrm{C}, 40.2 ; \mathrm{H}$, 5.4. Calc. for $\mathrm{C}_{8} \mathrm{H}_{14} \mathrm{O}_{8}$ (14 and 15): C, $40.34 ; \mathrm{H}, 5.92 \%$ ].

\section{Acknowledgements}

We thank Professor Lubineau for helpful discussions. The work was supported by Le Ministère des Affairs Etrangères (postdoctoral fellowship to N. L.) and Deutscher Akademischer Austauschdienst within the Procope program.

\section{References}

1 C. Augé, S. David, C. Gautheron, A. Malleron and B. Cavayé New J. Chem., 1988, 12,733, and references cited therein.

2 U. Kragl, D. Gygax, O. Ghisalba and C. Wandrey, Angew. Chem. 1991, 103, 854; Angew. Chem., Int. Ed. Engl., 1991, 30, 827; U. Kragl, D. Vasic-Racki and C. Wandrey, New Ind. J. Chem., Sect. B, 1993, 32 103 , and references cited therein.

3 C. Augé, B. Bouxom, B. Cavayé and C. Gautheron, Tetrahedron Lett., 1989, 30, 2217; C. Augé, C. Gautheron, S. David, A. Malleron, B. Cavayé and B. Bouxom, Tetrahedron, 1990, 46, 201.

4 M. D. Bednarski, D. C. Crans, R. Dicosimo, E. S. Simon, P. D. Stein and G. M. Whitesides, Tetrahedron Lett., 1988, 29, 427.

5 M. A. Ghalambor and E. C. Heath, J. Biol. Chem., 1966, 241, 3222; B. R. Knappmann and M.-R. Kula, Appl. Microbiol. Biotechnol. $1990,33,324$

6 T. Sugai, G. J. Shen, Y. Ichikawa and C. H. Wong, J. Am. Chem. Soc., 1993, 115, 413 .

7 This part of the work was presented at the XVIth International Carbohydrate Symposium in Paris, July 5-10, 1992

$8 \mathrm{C}$. Gautheron-Le Narvor, Y. Ichikawa and C. H. Wong, J. Am. Chem. Soc., 1991, 113, 7816

9 C. H. Lin, T. Sugai, R. L. Halcomb, Y. Ichikawa and C. H. Wong, $J$. Am. Chem. Soc., 1992, 114, 10138.

10 S. David, A. Malleron and B. Cavayé, New J. Chem., 1992, 16, 751.

11 R. Schauer, S. Stoll, E. Zbiral, E. Schreiner, H. H. Brandstetter, A Vasella and F. Baumberger, Glycoconjugate J., 1987, 4, 361.

12 F. M. Unger, Adv. Carbohydr. Chem. Biochem., 1981, 38, 388.

13 R. Cherniak, R. G. Jones and D. Sen Gupta, Carbohydr. Res., 1979, 75, 39 .

14 D. Charon and L. Szabo, J. Chem. Soc., Perkin Trans. I, 1980, 1971.

15 B. P. Bandgar, M. Hartmann, W. Schmid and E. Zbiral, Liebigs. Ann Chem., 1990, 1185.

16 T. Yamamoto, H. Kumazawa, K. Inami, T. Teshima and T. Shiba Tetrahedron Lett., 1992, 33, 5791.

17 R. Goldman, W. Kohlbrenner, P. Lartey and A. Pernet, Nature, 1987, 329, 162; H. G. Lerchen and H. P. Kroll, Angew. Chem., 1991, 103, 1728; Angew. Chem., Int. Ed. Engl., 1991, 30, 1682. 
18 W. Baumann, J. Freidenreich, G. Weisshaar, R. Brossmer and H. Friebolin, Biol. Chem. Hoppe-Seyler, 1989, 370, 141.

19 J. F. Stoddart, Stereochemistry of Carbohydrates, Wiley-Interscience, 1971 , p. 89.

20 G. G. Lilley, M. Vonitzstein and N. Ivancic, Prot. Express. Purif., 1992, 3, 434; Y. Ohta, Y. Tsukada, T. Sugimori, K. Murata and A.
Kimura, Agric. Biol. Chem., 1989, 53, 477; K. Aisaka, A. Igarashi, K. Yamaguchi and T. Uwajima, Biochem. J., 1991, 276, 541.

Paper 3/03979J Received 9th July 1993 Accepted 16th August 1993 